\title{
Customer involvement in greening the supply chain: an interpretive structural modeling methodology
}

\author{
Sanjay Kumar ${ }^{1 *}$, Sunil Luthra ${ }^{2}$ and Abid Haleem ${ }^{3}$
}

\begin{abstract}
The role of customers in green supply chain management needs to be identified and recognized as an important research area. This paper is an attempt to explore the involvement aspect of customers towards greening of the supply chain (SC). An empirical research approach has been used to collect primary data to rank different variables for effective customer involvement in green concept implementation in SC. An interpretive structural-based model has been presented, and variables have been classified using matrice d'impacts croises-multiplication appliqué a un classement analysis. Contextual relationships among variables have been established using experts' opinions. The research may help practicing managers to understand the interaction among variables affecting customer involvement. Further, this understanding may be helpful in framing the policies and strategies to green SC. Analyzing interaction among variables for effective customer involvement in greening SC to develop the structural model in the Indian perspective is an effort towards promoting environment consciousness.
\end{abstract}

Keywords: Supply chain, Green supply chain management, Green distribution, Interpretive structural modeling (ISM), MICMAC analysis

\section{Background}

Green supply chain management (GSCM) is the integration of both environmental and supply chain managements and has been identified as a proven way to reduce an organization's impact on the environment while improving business performance (Torielli et al. 2011).

Some studies have suggested that the customer plays an important role in greening the supply chain (SC). The requirement for organizations to respond actively to the customers' need has increasingly been important (Christopher 2000; Zhu and Sarkis 2004; Zhu et al. 2007a, 2007b; Zhu et al. 2008a, 2008b; Eltayeb et al. 2011). Consumer demands have been realized as a powerful pressure for change within organizations offering products or services in those markets. Consumers demand more value and quality from products, and since environmental awareness has increased, this type of pressure creates market opportunities in the form of environmental

\footnotetext{
* Correspondence: skbhardwaj19711971@gmail.com

'International Institute of Technology and Management, Murthal, Haryana 131039, India

Full list of author information is available at the end of the article
}

attributes and responsibility within the supply chain (Paquette 2005). The role of customers and environmental societies has been recognized for more environmentfriendly products (Vachon and Klassen 2006a). The influence on green supply chain initiatives had been followed by regulations and customer pressures (Eltayeb et al. 2011). Environmentally responsible organizations make themselves more attractive to customers and investors. The human factor plays an important role on both levels (Hanna et al. 2000; Lazuraz et al. 2011).

To improve the environmental supply chain performance, organizations need to make interactions with customers (Carter and Ellram 1998). Organizations implementing green concepts may compete and export their products in international markets. Organizations using improved environmental performance may lower their costs by reducing waste, also reducing their environmental compliance costs, and lessening the threats of civil and criminal liability by preventing pollution (Mudgal et al. 2009, 2010). Environmental collaboration with upstream suppliers and downstream customers has been found 
useful for organizations to reap performance gains (Vachon and Klassen 2008; Yang et al. 2009; Zhu et al. 2010).

Due to governmental legislations, environmental concerns, and customer awareness, more and more industries are giving attention to green practices (Thomas and Bijulal 2011; Wang and Gupta 2011). Customers having the choice of purchase and persuading organizations to act pro-environmentally may be possible by creating environmental consumer demand, when consumers request only environment-friendly products and refuse to buy products not meeting this requirement (H'Mida 2009).

GSCM practices have been about developing policies and practices protecting the environment along the supply chain and involve as many people as possible in this process, including manufacturers and suppliers, retailers, and customers (Zhu and Sarkis 2006; Lazuraz et al. 2011). Green supply chain programs may be initiated to position manufacturers to their customers or investors and to facilitate environmental compliance (IFS 2012).

Hence, the need arises to identify variables for effective customer involvement in the implementation of the green concept in SC. The main objectives of the research are the following:

- To identify variables for effective customer involvement in the implementation of the green concept in the supply chain.

- To prioritize the identified variables.

- To establish contextual relationships among the identified variables.

- To develop structural model using interpretive structural modeling (ISM) technique.

- To carry out matrice d'impacts croisesmultiplication appliqué a un classement (MICMAC) analysis to classify the variables.

The next section discusses literature review of the related work. In the 'Methods' section, subsections 'Identification of the variables for effective customer involvement in implementation of green concept in SC, 'Questionnairebased survey,' 'Interpretive structural modeling, and 'MICMAC analysis' of the problem are presented. Finally, the 'Results and discussion' section of this research are presented, followed by the 'Conclusions' section.

\section{Literature review}

Some researchers have attempted work related to customer perspective in greening the supply chain. The research work done by various researchers may be highlighted in chronological order as follows:

(Tan et al. 1998) explored the relationship among supplier management, customer relations, and organizational performance and used purchasing, quality, customer relations, and supplier closeness to evaluate the suitability of a supplier selection model. Hall (2000) suggested that large firms have to meet stakeholder pressure beyond legal environmental responsibilities, and many suppliers are under considerable pressures from their customers. (Hanna et al. 2000) suggested that operational improvements can be made through techniques as just-in-time manufacturing, total quality management, concurrent engineering, and employee involvement. Employee involvement in operational and environmental activities may cause cost reduction, process improvement, reduced process waste, improved morale, enhanced customer satisfaction, improved process safety, improved community relations, and an enhanced public perception as a green firm. Chan (2003) proposed SC performance measurement system which includes qualitative measures such as customer satisfaction, flexibility, information and material flow integration and effective risk management, and quantitative measures to evaluate the SC performance in terms of strategic planning, order planning, suppliers, production, and delivery. Theyel (2006) studied customer and supplier relations for achieving environmental performance in the US chemical industry and indicated that relations between customers and suppliers affect environmental performance by waste reduction. Vachon and Klasson (2006b) noted that environmental collaboration with suppliers and customers leads to improved manufacturing performance, such as improved quality, delivery, and flexibility.

(Simpson et al. 2007) explored the moderating impact of relationship conditions existing between a customer and suppliers and the effectiveness of the customer's environmental performance requirements. Zhu et al. (2007a) found five GSCM components or constructs including eco-design, green purchasing, internal environmental management, cooperation with customers, and investment recovery. Walker et al. (2008) stated that customer pressures on organizations vary depending on the size of the organization. Zhu et al. (2008a) studied GSCM practices in China's manufacturing industry, and GSCM practices have been divided into five primary dimensions: internal environmental management, green purchasing, eco-design, cooperation with customers, and investment recovery. These five dimensions of green SCM practices distinguish it from the traditional definitions of SCM. Zhu et al. (2008b) suggested that cooperation with suppliers and customers has become extremely critical for the organizations to close the supply chain loop. Wang et al. (2009) determined a methodology to identify customers who are satisfied and willing to pay more for green products in the consumer-oriented market where the consumers' behavior towards green product has become an important issue for business. 
(Azevedo et al. 2011) examined the relationships between green practices of supply chain management and supply chain performance in the context of the Portuguese automotive supply chain and obtained the conceptual model from data analysis providing evidence as to which green practices have positive effects on quality, customer satisfaction, and efficiency. Further, the practices having negative effects on supply chain performance were also identified in this study. Lazuras et al. (2011) suggested that the human factor plays an important role in the adoption and effective implementation of GSCM practices and presented a psychological perspective to GSCM adoption. Wu et al. (2011) evaluated supplier performance to find key factor criteria to improve performance. Results showed that the satisfied customer needs a criteria factor that has the greatest influence among the criteria for selecting suppliers. Green et al. (2012) suggested the model of green supply chain practices that link manufacturers with suppliers and customers to support environmental sustainability throughout the supply chain. The result suggested that organizations working with suppliers and customers achieve better environmental sustainability in the supply chain. Cooperation with customers is strongly associated with environmental performance. (Shi et al. 2012) suggested a structural model of natural resource-based GSCM and found intra- and interorganizational environmental practices, performance measures, and institutional drivers as important constructs. Causal relationships within and between the constructs were proposed in the form of hypotheses. Cooperation among customers has been found an important construct.

\section{Methods}

We have identified various variables for effective customer involvement in green concept implementation in the supply chain from the literature review and experts' opinions. Literature was reviewed to identify various variables for effective customer involvement in green concept implementation in supply chain. Experts from academia and industry were invited to idea engineering workshop, and brainstorming session was conducted where 13 variables relevant to effective customer involvement in green concept implementation in the supply chain were identified. A questionnaire-based survey was conducted to rank these variables. Using the ISM approach and MICMAC analysis technique, it had been identified that three variables ('Education Level of Customers', 'Customer Income', and 'Customer Intelligence') were falling into the category of autonomous variables, hence discarded, and research work had been continued with the remaining ten variables. Autonomous variables have weak driver power and weak dependence. These variables are relatively disconnected from the system, with which they have only few links, which may not be strong, and hence, may be discarded (Ravi and Shankar 2005; Mudgal et al. 2009, 2010; Luthra et al. 2011).

\section{Identification of variables for effective customer involvement in green concept implementation in the supply chain}

These variables identified for effective customer involvement in green concept implementation in the supply chain are as follows: 'Awareness Level of Customers,' 'Encouragement and Support of Customers,' 'Motivation by Organization Sales Network', 'Positive Perception about Top Management Commitment and Openness in Policy towards Greening,' 'Effective Advertisement and Marketing Campaign towards Green Efforts of Organization,' 'IT Enablement and Effective Communication,' 'Environment-Friendly Distribution,' 'Effective Training Program Schedule for Customer,' 'Green Labeling and Use of Green Packaging Material', and 'Recycling and Reuse Efforts of Organization.' The abovesaid identified variables are explained in the following subsections.

\section{Awareness level of customers}

Customers have been reported as strong drivers for greening activities in the literature (Green et al. 1996). Producing environment-friendly products and creating awareness among consumers are some of the ways through which companies can contribute towards nature conservation. Customer demands have a strong influence on the decisions that companies take towards eco-design (Alhola 2008). To obtain the most sustainable solution, the environment consideration of properties of products and services must meet customer requirement (Zhu et al. 2008a, 2008b).

\section{Encouragement and support of customers}

Some studies have found that ultimate individual consumer interest in the environment and environmentally sound products is quite substantial, even though there has been a slight decline (Reijonen 2011). Implementation of environmental technology may build a positive brand image, mitigate environmental liabilities associated with a firm's products and services, and influence the mindset of customers and investors (Rao and Holt $2005)$. In the USA, an estimated $75 \%$ of consumers claim that their purchases are influenced by reputation, and $80 \%$ would be willing to pay more for environmentfriendly products (Lamming and Hamapson 1996; Chien and Shih 2007a, 2007b).

\section{Motivation by organization sales network}

Customers are in direct contact with the organizations' sales personnel in most of the cases and may be informed, influenced, and convinced about the green products and 
services offered by the organizations. As one of the results of the brainstorming session, this factor was strongly recommended by the participants of the session.

\section{Positive perception about top management commitment and openness in policy towards greening}

Top management may be held responsible directly and indirectly for each activity at all the levels of the organizations (Singh and Kant 2008). Top management commitment is necessary for supporting GSCM ideas, practices, and cooperation across organizational functions (Sarkis et al. 2007; Zhu et al. 2007a, 2007b), and success of any strategic program needs to be derived from top management (Yu and Hui 2008). Top management has a significant ability to support actual formation and implementation of green initiatives across the organization. Top management may provide continuous support for GSCM in the strategic and action plans for successful implementation (Ravi and Shankar 2005; Mudgal et al. 2009). Positive perception about top management commitment and openness in policy towards greening may be achieved by publishing sincere green efforts of organization.

\section{Effective advertisement and marketing campaign towards green efforts of organization}

Organizations may advertise environment-friendly products and services to create awareness among customers. Customers aware of green products may prefer to purchase green products, which may further increase an organization's reputation and sales volumes (Luthra et al. 2011). Newspapers, hording, magazines, printed material distribution (leaflets, booklets, etc.), and various audiovisual media (e.g., radio, television,cinema) may be a few media for advertisement and marketing campaign for making the customers more aware of green efforts of the organization. In India, few retail organizations are providing recycled paper and jute bags (with green slogans) for carrying their products.

\section{IT enablement and effective communication}

IT enablement may be required for processing and updating accurate information of products, materials, and other resources (Sarkis et al. 2007) and for supporting various GSCM activities (Ravi and Shankar 2005). Informal linkages and improved communication may help the organization to adopt green practices ( $\mathrm{Yu}$ 2007; Yu and Hui 2008), and increased environmental performance in GSCM may be achieved by information sharing of improved quality (Wu et al. 2010).

\section{Environment-friendly distribution}

Environment-friendly or green distribution is the process of moving a product from its manufacturing source to its customers with a low impact on the environment.
Reverse logistics is identified as the process of planning, implementing, and controlling flows of raw materials, in-process inventory, and finished goods from a manufacturing, distribution, or use point to a point of recovery or point of proper disposal (Ilgin and Gupta 2010; Srivastva 2007). The use of green fuel-like compressed natural gas-driven vehicles may exhibit seriousness about green efforts of an organization.

\section{Effective training program schedule for customers}

Training and education are the prime requirements for achieving successful implementation of GSCM in any organization (Ravi and Shankar 2005; Sarkis et al. 2007; $\mathrm{Wu}$ et al. 2010). Trained personnel may contribute in training the customers, leading to better customer involvement in GSCM implementation.

\section{Green labeling and use of green packing material}

Environment-friendly packing refers to use of recyclable or dissolvable materials for packing and has a clear objective of encouraging business to market greener products (Fielding 2001), and it may be a good way to make the customers better informed about environmental choices while purchasing. Eco-labeling is a voluntary scheme designed to encourage businesses to market environmentfriendly products and services (Mudgal et al. 2009).

\section{Recycling and reuse efforts of organization}

Recycling is the process of collecting used products, components, and materials from the field and separating them into categories of like materials (recyclable and nonrecyclable), and recyclable materials may be processed into recycled products, components, and materials. Reuse is the process of collecting used materials, products, or components from the field, and distributing or selling them as used. Waste management and recyclability evaluation methods may help in managing and minimizing waste and improving the environment (Ilgin and Gupta 2010; Srivastva 2007). Lean is a competitive practice that reduces costs, improves the environment, and improves quality (Bhetja et al. 2011). The use of lean or flexible manufacturing may help in the continuous improvement and elimination of waste in all forms and has great potential for reciprocal benefits to firm environmental management practices (Mudgal et al. 2009).

\section{Questionnaire-based survey}

Based upon the abovesaid variables for effective customer involvement in green concept implementation in the supply chain, a research questionnaire was designed. The questionnaire was developed taking into account the experts' opinions. A first draft was reviewed by experts from the academia and industry. Their feedback was used to improve the questions and eliminate 
redundancies. A second version was developed. These variables were tested for content validity and reliability through the pretesting of the questionnaire. Content validity is the technique used to ensure that the measures adequately quantify the concepts that they are supposed to be tested (Sekaran 2003). Reliability concerns the extent to which an experience, test, or any measuring procedure yields the same results on repeated trials (Carmines and Zeller 1979). Reliability evaluates the accuracy of measures through assessing the internal stability and consistency of items in each variable (Hair et al. 2009). Validity of the variables was pretested among selected experts from the academia and industry. The reliability of measures was also pretested by applying Cronbach's alpha coefficients on the responses from experts. All values of the coefficients fall within the range of 0.60 to 0.80 , ensuring an acceptable level of reliability (Nunnally 1987). The results from this pretest were used to further improve the questionnaire. After a discussion with the experts and the pretest, we kept our questionnaire very simple and short due to low rate of responses from respondents. After pretesting, the final version will be used in the survey. The population of this study consists of academicians, manufacturing firms, and valuable customers from North Indiasince the population size was very large. After identifying the target population, it was necessary to determine the sample size. The sample size was taken using the following mathematical relationship for proportions (Israel 1996; Rea and Parker 2005; Sanchez Gomez 2011).

$$
\text { Sample size }=\mathrm{Z}^{2} \times \mathrm{p} \times(1-\mathrm{p}) / H 2
$$

where $Z=Z$ value in normal distribution tables (1.96 for 95\% confidence level), $p=$ the estimated proportion of the population that presents the characteristics $(0.5$ is used as a conservative value, higher or lower values yield a smaller required sample size), and $H=$ the precision level or margin of error, expressed as decimal $(10 \%=0.1)$. Then, sample size $=(1.96)^{2} \times 0.5(1-0.5) /(0.1)^{2}=96.04$ or sample size $=96$.

Therefore, approximately 96 complete questionnaires were needed. A questionnaire-based study was carried out, and respondents were asked to rank the variables on a five-point Likert scale (where ' 1 ' means not important and ' 5 ' means most important). This research was conducted from August 2011 to November 2012 at the North India zone. We used convenience sampling as well as random sampling. Due to difficulties of mail surveys and the possibility of respondents to misunderstand the questionnaire items, we used convenience sampling through interviewing various academicians, top/middle level managers/engineers of industries, and customers. One hundred seventy-eight completed questionnaires were collected via interviews. Further, to test the convenience sampling bias, we carried out random surveys through e-mail; 643 questionnaires were sent to various academicians, top/middle level managers/engineers of various industries, and customers. After reminder emails in addition to telephonic calls, 171 questionnaires were received. Twenty-seven questionnaires were incomplete and were discarded. This gives an overall response rate of $22.4 \%$. A response rate of $20 \%$ is considered for positive assessment of the surveys (Malhotra and Grover 1998). A total of 322 questionnaires were considered for further research work.

\section{Interpretive structural modeling}

The mathematical foundations of the ISM methodology can be found in reference works (Harary et al. 1965), while the philosophical basis for the development of this approach has been presented by Warfield (1974). ISM has been used for policy analysis (Sage 1977) and, in recent years, for management research (Mandal and Deshmukh 1994; Jharkharia and Shankar 2005; Ravi and Shankar 2005; Sushil 2005; Sarkis et al. 2007; Mudgal et al. 2009, 2010; Diabat and Kannan 2011; Luthra et al. 2011). ISM was first proposed by J. Warfield in 1974 to analyze the complex socioeconomic systems. Its basic idea is to use the experts' practical experience and knowledge to decompose a complicated system into several subsystems and construct a multilevel structural model. The ISM is interpretive as the judgment of the selected group for the study decides whether and how the factors are interrelated. ISM generally has the following steps (Ravi and Shankar 2005; Sage 1977; Warfield 1974):

Step 1: Variables affecting the system are listed.

Step 2: From the variables identified in step 1, the contextual relationships among the variables are found.

Step 3: A structural self-interaction matrix (SSIM) is developed for variables, which indicated pairwise relationships among variables of the system.

Step 4: A reachability matrix is developed from the SSIM, and the matrix is checked for transitivity. The transitivity of the contextual relation is a basic assumption made in ISM. It states that if variable $A$ is related to variable $B$ and variable $B$ is related to variable $C$, then variable $A$ is necessarily related to variable $C$.

Step 5: The reachability matrix obtained in step 4 is partitioned into different levels.

Step 6: Based on the contextual relationships given above in the reachability matrix, a directed graph is drawn and the transitive links are removed. 
Step 7: The resultant diagraph is converted into an ISM by replacing variable nodes with statements.

Step 8: The ISM model developed in step 7 is reviewed to check for conceptual inconsistency, and necessary modifications are made.

The flow chart for the ISM methodology is shown in Figure 1.

\section{MICMAC analysis}

Matrice d'impacts croises-multipication applique' an classment (cross-impact matrix multiplication applied to classification) is abbreviated as MICMAC (Mudgal et al. 2009). In the MICMAC analysis, the dependence power and driver power of the variables are analyzed. Variables will be classified into four clusters. The four clusters are autonomous, dependent, linkage, and driver/independent. In the final reachability matrix, the driving power and dependence power of each of the variables will be plotted. Autonomous variables (first cluster) have weak driving power and weak dependence power. These variables can be disconnected from the system. The second clusters named dependent variables have weak driving power and strong dependence power. The third cluster named linkage variables has strong driving power and strong dependence power. The fourth cluster named independent variables has strong driving power and weak dependence power.

\section{Results and discussion}

The results and discussions of questionnaire-based survey, interpretive structural modeling technique, and MICMAC analysis have been discussed in the following subsections, respectively.

\section{Questionnaire-based survey}

Questionnaire-based data have been further processed with the help of the software package Minitab version 16. The values of mean, standard error of mean, trimmed mean, standard deviation, variance, and rank for each variable have been tabulated in Table 1. Five percent of the highest and five percent of the lowest data values are excluded for the calculation the trimmed

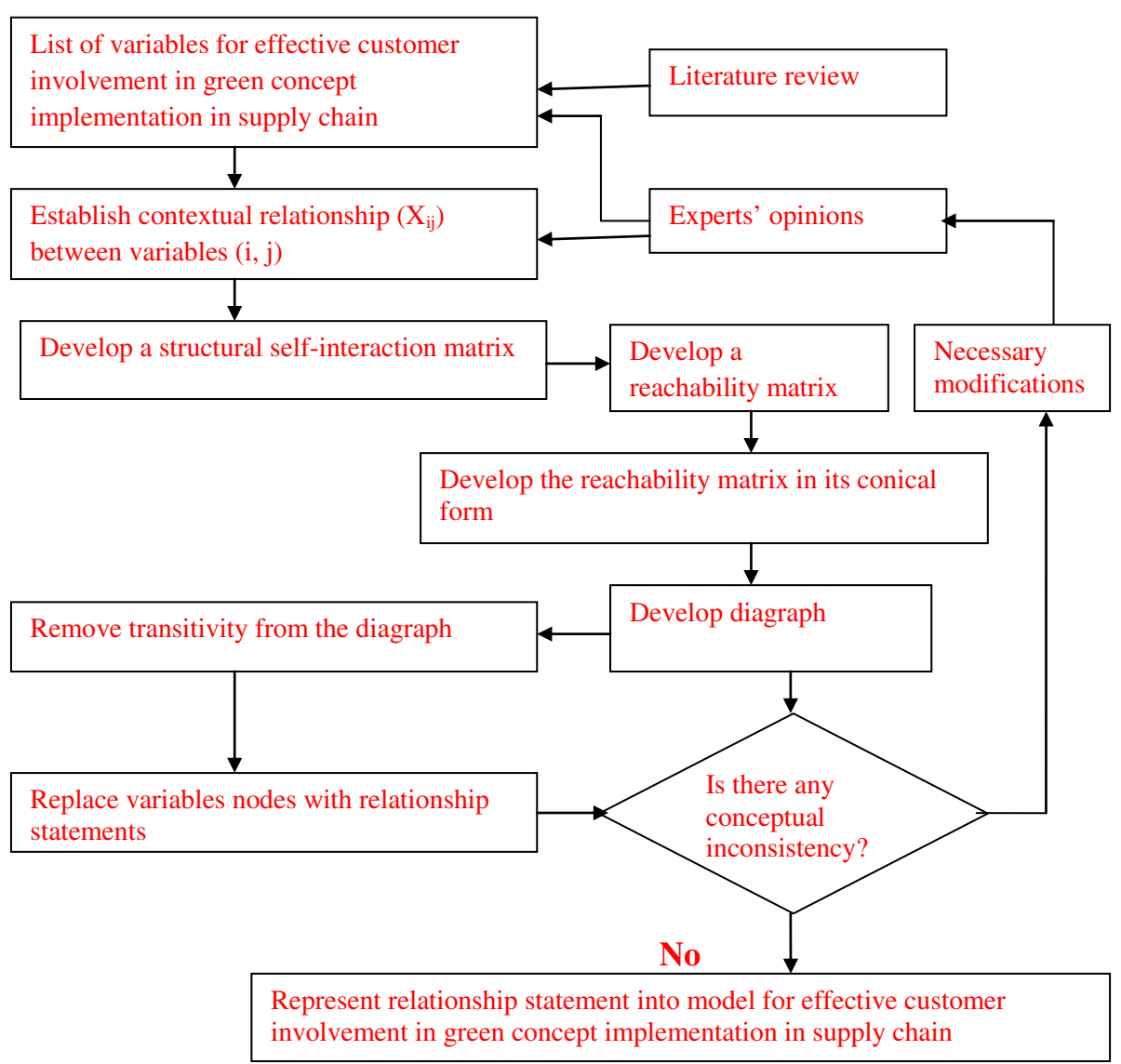

Figure 1 Flow chart for ISM methodology (Ravi and Shankar 2005). 
Table 1 Statistical data analysis result

\begin{tabular}{|c|c|c|c|c|c|c|c|}
\hline Number & Variable & Mean & $\begin{array}{l}\text { Standard } \\
\text { error mean }\end{array}$ & $\begin{array}{l}\text { Trimmed } \\
\text { mean }\end{array}$ & $\begin{array}{l}\text { Standard } \\
\text { deviation }\end{array}$ & Variance & Rank \\
\hline 1 & Awareness level of customers & 3.2688 & 0.0476 & 3.2425 & 0.9187 & 0.8440 & $x$ \\
\hline 2 & Encouragement and support of customers & 3.2124 & 0.0454 & 3.1886 & 0.8753 & 0.7661 & IX \\
\hline 3 & Motivation by organization sales network & 3.6371 & 0.0330 & 3.6078 & 0.6359 & 0.4043 & VIII \\
\hline 4 & $\begin{array}{l}\text { Positive perception about top management } \\
\text { commitment and openness in policy } \\
\text { towards greening }\end{array}$ & 3.6882 & 0.0329 & 3.6766 & 0.6355 & 0.4038 & VII \\
\hline 5 & $\begin{array}{l}\text { Effective advertisement and marketing } \\
\text { campaign towards green efforts of organization }\end{array}$ & 4.0838 & 0.0297 & 4.0994 & 0.5712 & 0.3263 & V \\
\hline 6 & IT enablement and effective communication & 4.0538 & 0.0320 & 4.0689 & 0.6163 & 0.3799 & $\mathrm{Vl}$ \\
\hline 7 & Environment-friendly distribution & 4.4785 & 0.0288 & 4.5090 & 0.5563 & 0.3095 & $\|$ \\
\hline 8 & $\begin{array}{l}\text { Effective training program schedule } \\
\text { for customers }\end{array}$ & 4.7339 & 0.0233 & 4.7635 & 0.4486 & 0.2012 & I \\
\hline 9 & Green labeling and use of green packing material & 4.3925 & 0.0308 & 4.4371 & 0.5935 & 0.3523 & III \\
\hline 10 & Recycling and reuse efforts of organization & 4.3172 & 0.0300 & 4.3533 & 0.5795 & 0.3358 & IV \\
\hline
\end{tabular}

mean. Ranking of variables has been done on the basis of the trimmed mean.

'Effective training program schedule for customers,' 'Environment-friendly distribution', and 'Green labeling and use of green packaging material' have been ranked by respondents as the top three variables.

'Effective training program schedule for customers' has also been observed having the lowest standard deviation and lowest variance. 'Awareness level of customers' has been observed having the highest standard deviation and highest variance. Variance and standard deviation measure variability within a distribution. Standard deviation indicates how much, on average, each of the values in the distribution deviates from the mean of the distribution. Higher standard deviation means having large variations in the data, and lower standard deviation means having small variations in the data. Lower standard deviation will indicate the reliability of data. Variance is the average squared deviations of the mean.

The coefficients of correlation among variables have been tabulated in Table 2. Maximum value of coefficient of correlation has been indentified between 'Awareness level of customers' and 'Encouragement and support of customers.'

These correlation coefficients of different variables have been classified according to the rules of thumb about the strength of correlation coefficient (Hair et al. 2003, p.568). These variables have been classified into five categories (Table 3). 'Awareness level of customer' and 'Encouragement and support of customers,' 'Motivation by organization sales network', and 'Positive perception about top management commitment and openness in policy towards greening', and 'Effective advertisement and Marketing campaign towards green efforts of organization' and 'IT enablement and effective communication' have been classified as strongly correlated variables.

\section{Interpretive structural modeling}

ISM can be used for identifying and summarizing relationships among specific variables, which define a problem or an issue (Warfield 1974; Sage 1977). It provides means by which order can be imposed on the complexity of such variables (Mandal and Deshmukh 1994; Jharkharia and Shankar 2005; Luthra et al. 2011).

\section{Structural self-interaction matrix}

ISM model suggests the use of experts' opinions in identifying the contextual relationship among variables. Thus, in this research for identifying the contextual relationship among the variables for effective customer involvement in green concept implementation in SC, three experts from the academia and four experts from the industry were consulted. Four symbols (V, A, X, and O) are used to denote the direction of the relationship between the variables $(i$ and $j$ ): $\mathrm{V}$ - variable $i$ will lead to variable $j$, A- variable $j$ will lead to variable $i$, X-variable $i$ and $j$ will lead to each other, and O- variable $i$ and $j$ are unrelated.

Based on the contextual relationships, SSIM has been developed (Table 4). Variable 9 leads to variable 10, so symbol ' $\mathrm{V}$ ' has been given in the cell $(9,10)$; variable 3 leads to variable 1 , so symbol 'A' has been given in the cell $(1,3)$; variables 1 and 2 lead to each other, so symbol ' $\mathrm{X}$ ' has been given in the cell $(1,2)$; variables 6 and 7 do not lead to each other, so symbol ' $O$ ' has been given in the cell $(6,7)$, and so on. The number of pairwise comparison question addressed for developing the SSIM are $((N) \times$ $(N-1) / 2)$, where $N$ is the number of variables. 
Table 2 Coefficient of correlation of variables

\begin{tabular}{lllllllllll}
\hline Variable & $\mathbf{1}$ & $\mathbf{2}$ & $\mathbf{3}$ & $\mathbf{4}$ & $\mathbf{5}$ & $\mathbf{6}$ & $\mathbf{7}$ & $\mathbf{8}$ & $\mathbf{9}$ \\
\hline 1 & 1.000 & 0.776 & 0.226 & 0.276 & 0.159 & 0.139 & 0.069 & 0.060 & 0.069 & $\mathbf{1 0}$ \\
2 & 0.776 & 1.000 & 0.149 & 0.169 & 0.186 & 0.165 & 0.101 & 0.097 & 0.012 & 0.117 \\
3 & 0.226 & 0.149 & 1.000 & 0.606 & 0.084 & 0.124 & 0.004 & -0.011 & -0.082 & -0.002 \\
4 & 0.276 & 0.169 & 0.606 & 1.000 & 0.132 & 0.145 & 0.088 & 0.009 & -0.092 & 0.012 \\
5 & 0.159 & 0.186 & 0.084 & 0.132 & 1.000 & 0.612 & 0.351 & 0.193 & 0.183 & 0.255 \\
6 & 0.139 & 0.165 & 0.124 & 0.145 & 0.612 & 1.000 & 0.236 & 0.118 & 0.042 & 0.099 \\
7 & 0.069 & 0.101 & 0.004 & 0.088 & 0.351 & 0.236 & 1.000 & 0.437 & 0.288 & 0.387 \\
8 & 0.060 & 0.097 & -0.011 & 0.009 & 0.193 & 0.118 & 0.437 & 1.000 & 0.320 & 0.284 \\
9 & 0.069 & 0.012 & -0.082 & -0.092 & 0.183 & 0.042 & 0.288 & 0.320 & 1.000 & 0.287 \\
10 & 0.086 & 0.117 & -0.002 & 0.012 & 0.255 & 0.099 & 0.387 & 0.284 & 0.287 & 1.000 \\
\hline
\end{tabular}

The use of symbols V, A, X, and O may be clearly understood from SSIM made after reaching to a consensus in the opinions of experts (Table 4):

\section{Reachability matrix}

SSIM has been converted into a binary matrix, named initial reachability matrix, by substituting $\mathrm{V}, \mathrm{A}, \mathrm{X}$, and $\mathrm{O}$ by 1 or 0 applying the following rules:

- If $(i, j)$ value in the SSIM is $\mathrm{V},(i, j)$ value in the reachability matrix will be 1 and $(j, i)$ value will be 0 ; for $\mathrm{V}(9,10)$ in SSIM, ' 1 ' has been given in cell $(9,10)$ and ' 0 ' in cell $(10,9)$ in the initial reachability matrix.

- If $(i, j)$ value in the SSIM is A, $(i, j)$ value in the reachability matrix will be 0 and $(j, i)$ value will be 1 ; for A $(1,3)$ in SSIM, ' 0 ' has been given in cell $(1,3)$ and ' 1 ' in cell $(3,1)$ in the initial reachability matrix.

- If $(i, j)$ value in the SSIM is X, $(i, j)$ value in the reachability matrix will be 1 and $(j, i)$ value will also be 1 ; for $\mathrm{X}(1,2)$ in SSIM, ' 1 ' has been given in cell $(1,2)$ and ' 1 ' in cell $(2,1)$ also in the initial reachability matrix.
- If $(i, j)$ value in the SSIM is O, $(i, j)$ value in the reachability matrix will be 0 and $(j, i)$ value will also be 0 ; for $\mathrm{O}(6,7)$ in SSIM, '0' has been given in cell $(6,7)$ and ' 0 ' in cell $(7,6)$ also in initial reachability matrix.

By applying these rules, an initial reachability matrix for variables for effective customer involvement in green concept implementation in the supply chain has been obtained (Table 5).

The final reachability matrix (Table 6) is constructed from the initial reachability matrix taking into account the transitivity rule, which states that if a variable ' $\mathrm{A}$ ' is related to ' $\mathrm{B}$ ' and ' $\mathrm{B}$ ' is related to ' $\mathrm{C}$ ', then ' $\mathrm{A}$ ' is necessarily related to ' $C$ '. Variable 5 leads to variables $1,2,3,4$, and 6. Variable 7 leads to variables $1,2,3,4$, and 5, and then variable 6 must be added to variable 7 as transitive element and so on.

In Table 6, the driving power and the dependence of each enabler are also shown. The driving power for each variable is the total number of variables (including itself), intowhich it may impact. Dependence is the total

Table 3 Classification of variables based upon significance of correlation

\begin{tabular}{|c|c|c|c|c|c|}
\hline Variable number & Very strongly correlated $^{a}$ & Strongly correlated $^{\mathbf{b}}$ & Moderately correlated $^{c}$ & Weakly correlated $^{\mathrm{d}}$ & Not correlated $^{\mathrm{e}}$ \\
\hline 1 & 1 & 2 & & 3,4 & $5,6,7,8,9,10$ \\
\hline 2 & 2 & 1 & & & $3,4,5,6,7,8,9,10$ \\
\hline 3 & 3 & 4 & & 1 & $2,5,6,7,8,9,10$ \\
\hline 4 & 4 & 3 & & 1 & $2,5,6,7,8,9,10$ \\
\hline 5 & 5 & 6 & & 7,10 & $1,2,3,4,8,9$ \\
\hline 6 & 6 & 5 & & 7 & $1,2,3,4,8,9,10$ \\
\hline 7 & 7 & & 8 & $5,6,9,10$ & $1,2,3,4$ \\
\hline 8 & 8 & & 7 & 9,10 & $1,2,3,4,5,6$ \\
\hline 9 & 9 & & & $7,8,10$ & $1,2,3,4,5,6$ \\
\hline 10 & 10 & & & $5,7,8,9$ & $1,2,3,4,6$ \\
\hline
\end{tabular}

${ }^{a}$ Variable numbers having a correlation coefficient between 0.801 and $1.000 ;{ }^{b}$ variable numbers having a correlation coefficient between 0.601 and $0.800 ;{ }^{c}$ variable numbers having a correlation coefficient between 0.401 and $0.600 ;{ }^{d}$ variable numbers having a correlation coefficient between 0.201 and 0.400 ; ${ }^{e}$ variable numbers having a correlation coefficient less than or equal to 0.200 . 
Table 4 Structural self interaction matrix

\begin{tabular}{llllllllll}
\hline Variable & $\mathbf{1 0}$ & $\mathbf{9}$ & $\mathbf{8}$ & $\mathbf{7}$ & $\mathbf{6}$ & $\mathbf{5}$ & $\mathbf{4}$ & $\mathbf{3}$ & $\mathbf{2}$ \\
\hline 1 & A & A & A & A & A & A & A & A & X \\
2 & A & A & A & A & A & A & A & A & \\
3 & A & A & A & A & A & A & X & & \\
4 & A & A & A & A & A & A & & \\
5 & A & A & A & A & X & & & \\
6 & O & O & O & O & & & & \\
7 & X & A & O & & & & & \\
8 & O & A & & & & & & & \\
9 & V & & & & & & & & \\
\hline
\end{tabular}

number of variables (including itself), which may be impacting it. These driving power and dependencies will be used in the MICMAC analysis, where the variables will be classified into four groups of autonomous, dependent, linkage, and independent (driver) variables.

\section{Level partitioning}

The reachability set and antecedent set (Warfield 1974) for each variable have been found out from final reachability matrix. Subsequently, the intersection set of these sets has been derived for all variables. The variable, for which the reachability and the intersection sets are the same, has been given the top-level variable in the ISM hierarchy. From Table 7, it is seen that the 'Awareness Level of Customers' and 'Encouragement and Support of Customers' have been found at Level I. The iteration is continued until the level of each variable is found out. The identified levels aid in building the diagraph and the final model of the ISM.

From the final reachability matrix, the structural model generated is known as a diagraph. After removing the transitivity links and replacing the node numbers by statements, the ISM model has been generated, which has been shown in Figure 2. It is observed from the figure that 'Green labeling and use of green packaging

Table 5 Initial reachability matrix

\begin{tabular}{lllllllllll}
\hline Variable & $\mathbf{1}$ & $\mathbf{2}$ & $\mathbf{3}$ & $\mathbf{4}$ & $\mathbf{5}$ & $\mathbf{6}$ & $\mathbf{7}$ & $\mathbf{8}$ & $\mathbf{9}$ & $\mathbf{1 0}$ \\
\hline 1 & 1 & 1 & 0 & 0 & 0 & 0 & 0 & 0 & 0 & 0 \\
2 & 1 & 1 & 0 & 0 & 0 & 0 & 0 & 0 & 0 & 0 \\
3 & 1 & 1 & 1 & 1 & 0 & 0 & 0 & 0 & 0 & 0 \\
4 & 1 & 1 & 1 & 1 & 0 & 0 & 0 & 0 & 0 & 0 \\
5 & 1 & 1 & 1 & 1 & 1 & 1 & 0 & 0 & 0 & 0 \\
6 & 1 & 1 & 1 & 1 & 1 & 1 & 0 & 0 & 0 & 0 \\
7 & 1 & 1 & 1 & 1 & 1 & 0 & 1 & 0 & 0 & 1 \\
8 & 1 & 1 & 1 & 1 & 1 & 0 & 0 & 1 & 0 & 0 \\
9 & 1 & 1 & 1 & 1 & 1 & 0 & 1 & 1 & 1 & 1 \\
10 & 1 & 1 & 1 & 1 & 1 & 0 & 1 & 0 & 0 & 1 \\
\hline
\end{tabular}

material' is a very significant variable for effective customer involvement in green concept implementation in $\mathrm{SC}$ as it comes at the base of the ISM hierarchy. 'Awareness level of customers' and 'Encouragement and support of customers' are the top-level variables in the model.

The structural model for effective customer involvement in greening the supply chain, presented in the study, addresses the importance of customer role in the process of making the SC sustainable. 'Use of green packing material' supports 'Recycling and reuse efforts of the organization' and 'Environment-friendly distribution.' Also, 'Environment-friendly distribution' may be utilized for recollecting used and/or discarded (due to improper quality or because of any other reason) products/components. In India, an unorganized sector involves collection of junk/waste/scrap material by ragpickers and selling to big dealers. Here, authors want to draw the attention towards this area ('Kabaadi-Wala' SC) for future research having green potential for research focusing upon the 'recycling and reuse' aspect. Green labeling of products with appropriate display of information about greening may be proven as an important help to train the customers, which may further facilitate effective communication among various actors in the greening process. 'Environment-friendly distribution' system may itself be utilized as a strong way of advertising and publicized in the organization's marketing campaign. IT enablement, effective communication, advertisement, and marketing campaign may complement and help each other towards green efforts of organization and, further, may help in motivating customers by sales personnel and having a positive perception about top management efforts towards greening. However, this may lead to developing the trust of customers on top management sincerity for greening. All the above factors in totality may lead to a high level of customer awareness, encouragement, and support.

\section{MICMAC analysis}

MICMAC analysis is done with the help of driving power and dependence power of variables. The driver power-dependence diagram has been constructed and is shown in Figure 3.

The first cluster consists of the autonomous variables that have weak driver power and weak dependence. No variable has been identified as an autonomous variable. The second cluster consists of the dependent variables that have weak driver power but strong dependence. 'Awareness level of customers,' 'Encouragement and support of customers,' 'Motivation by organization sales network', and 'Positive perception about top management commitment and openness in policy towards greening' have been identified as dependent variables. The third cluster has the linkage variables that have strong driver 
Table 6 Final reachability matrix

\begin{tabular}{lcccccccccccc}
\hline Variables & $\mathbf{1}$ & $\mathbf{2}$ & $\mathbf{3}$ & $\mathbf{4}$ & $\mathbf{5}$ & $\mathbf{6}$ & $\mathbf{7}$ & $\mathbf{8}$ & $\mathbf{9}$ & $\mathbf{1 0}$ & $\begin{array}{c}\text { Driver } \\
\text { power }\end{array}$ & $\begin{array}{l}\text { Driver } \\
\text { rank }\end{array}$ \\
\hline 1 & 1 & 1 & 0 & 0 & 0 & 0 & 0 & 0 & 0 & 0 & 2 & $\mathrm{VI}$ \\
2 & 1 & 1 & 0 & 0 & 0 & 0 & 0 & 0 & 0 & 0 & 2 & $\mathrm{VI}$ \\
3 & 1 & 1 & 1 & 1 & 0 & 0 & 0 & 0 & 0 & 0 & 4 & $\mathrm{~V}$ \\
4 & 1 & 1 & 1 & 1 & 0 & 0 & 0 & 0 & 0 & 0 & 4 & $\mathrm{~V}$ \\
5 & 1 & 1 & 1 & 1 & 1 & 1 & 0 & 0 & 0 & 0 & 6 & $\mathrm{IV}$ \\
6 & 1 & 1 & 1 & 1 & 1 & 1 & 0 & 0 & 0 & 0 & 6 & $\mathrm{~N}$ \\
7 & 1 & 1 & 1 & 1 & 1 & $1^{\mathrm{a}}$ & 1 & 0 & 0 & 1 & 8 & $\|$ \\
8 & 1 & 1 & 1 & 1 & 1 & $1^{\mathrm{a}}$ & 0 & 1 & 0 & 0 & 6 & $\mathrm{II}$ \\
9 & 1 & 1 & 1 & 1 & 1 & $1^{\mathrm{a}}$ & 1 & 1 & 1 & 1 & 10 & $\mathrm{I}$ \\
10 & 1 & 1 & 1 & 1 & 1 & $1^{\mathrm{a}}$ & 1 & 0 & 0 & 1 & 8 & $\|$ \\
Dependence & 10 & 10 & 8 & 8 & 6 & 6 & 3 & 2 & 1 & 3 & & \\
Dependence rank & $\mathrm{I}$ & $\mathrm{I}$ & $\|$ & $\|$ & $\| \mathrm{II}$ & $\mathrm{IV}$ & $\mathrm{V}$ & $\mathrm{VI}$ & $\mathrm{NV}$ & & \\
\hline
\end{tabular}

${ }^{\mathrm{a}}$ Means transitive.

power and also strong dependence. 'Effective advertisement and marketing campaign towards green efforts of organization,' and 'IT enablement and effective communication' have been found out as linkage variables in our study. The fourth cluster includes the independent variables having strong driving power but weak dependence. 'Environment-friendly distribution,' 'Effective training program schedule for customers,' 'Green labeling and use of green packaging material', and 'Recycling and reuse efforts of organization' have been identified as the driver variables.

\section{Conclusions}

Greening of SC has been identified as an important approach for improving the environmental performance of processes and products. Ten variables for effective customer involvement in green concept implementation

Table 7 Partitioning of variables

\begin{tabular}{lllll}
\hline Variables & $\begin{array}{l}\text { Reachability } \\
\text { set }\end{array}$ & Antecedent set & $\begin{array}{l}\text { Intersection } \\
\text { set }\end{array}$ & Level \\
\hline 1 & 1,2 & $1,2,3,4,5,6,7,8,9,10$ & 1,2 & I \\
2 & 1,2 & $1,2,3,4,5,6,7,8,9,10$ & 1,2 & I \\
3 & $1,2,3,4$ & $3,4,5,6,7,8,9,10$ & 3,4 & II \\
4 & $1,2,3,4$ & $3,4,5,6,7,8,9,10$ & 3,4 & II \\
5 & $1,2,3,4,5,6$ & $5,6,7,8,9,10$ & 5,6 & II \\
6 & $1,2,3,4,5,6$ & $5,6,7,8,9,10$ & 5,6 & II \\
7 & $1,2,3,4,7,5,6,10$ & $7,9,10$ & 7,10 & IV \\
8 & $1,2,3,4,5,6,8$ & 8,9 & 8 & IV \\
9 & $1,2,3,4,5,6,7,9,10,8$ & 9 & 9 & V \\
10 & $1,2,3,4,5,6,7,10$ & $7,9,10$ & 7,10 & VI \\
\hline
\end{tabular}

in SC have been identified from the literature. These variables have been validated from a questionnaire-based survey.

ISM methodology has been used in finding contextual relationships among various variables. A model has been developed from ISM methodology. 'Awareness level of customers' and 'Encouragement and support of customers' have been identified as top-level variables and 'Green labeling and use of green packing material' as the most important bottom-level variable. MICMAC analysis has also been carried out. The driving powerdependence power diagram helps to categorize various variables for effective customer involvement in the implementation of green concept in the supply chain. Four variables have been identified as driver variables and four variables as dependent variables. Two variables have been identified as linkage variables and no variable as autonomous variable. Dependent variables represent desired objectives for customer involvement in greening the supply chain. Driver variables will play an important driving role in customer involvement in greening the supply chain. Management needs to address these variables more carefully. Linkage variables are unstable that any action on these variables will have an effect on others and also a feedback on themselves.

Human factor plays a major role in 'greening' the supply chain. The legislative framework and regulations promoting environmental practices cannot guarantee GSCM adoption, unless the dynamic interplay between the people involved throughout the SC is taken into consideration (Lazuras et al. 2011).

The customer has been reported as repeated enabler in the literature. Some researchers identified cooperation of customers with eco-design, cleaner production, and using less energy during product transportation and green design as an important variable (Zhu and Sarkis 2004; Zhu et al. 2007a, 2007b; Zhu et al. 2008a, 2008b; Green et al. 2012). Our study identifies ten variables for effective customer involvement in the implementation of green concept in supply chain.

Consumer demand for eco-friendly goods is increasing. A large number of customers prefer organizations that have superior environmental records and greener products and are ready to pay a premium for it (Lakshmi and Visalakshmi 2012). Organizations have begun to implement GSCM practices in response to customer demand (Green et al. 2012). Customers have impacted on the decisions of manufacturing enterprises to employ GSCM practices (Huang 2012). With increasing customer awareness and regulatory norms, organizations with greener supply chain may have a competitive advantage (Cognizant 2009).

Earlier studies did not provide a structural model of customer involvement in greening the supply chain in 


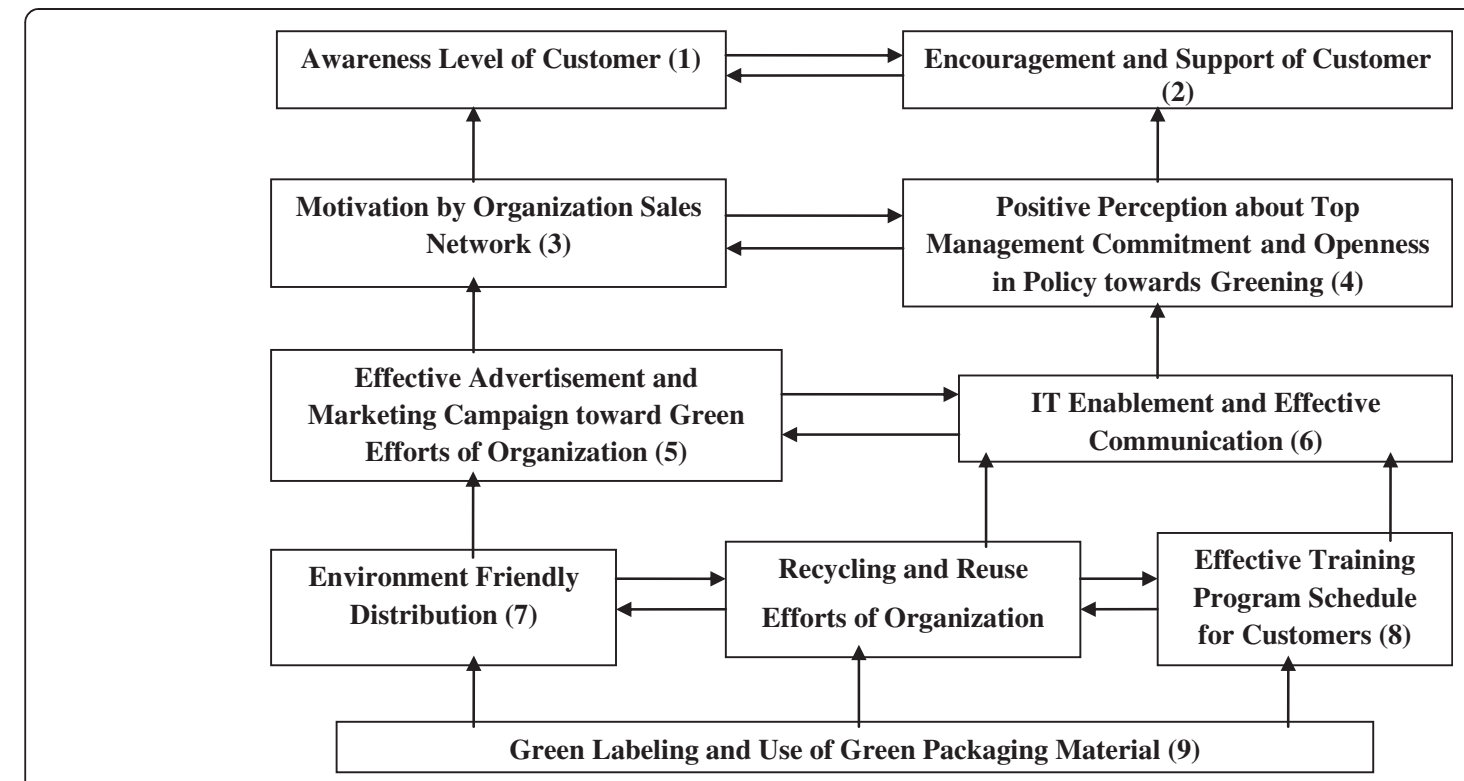

Figure 2 ISM-based model of variables for effective customer involvement in green concept implementation in supply chain management.

the Indian context. Further, this study provided hierarchy of variables for effective customer involvement in green concept implementation in the supply chain; this hierarchy may help managers/supply chain practitioners in strategic and tactical decisions towards customer involvement in green practices. Customers aware of green products would like to purchase green products, which may increase an organization's reputation and sales volumes (Mudgal et al. 2009; Luthra et al. 2011).
The model developed in this research is based upon experts' opinions. The experts' opinion may be biased. The results of model analysis may vary in real world setting. We have considered ten variables. In case a model needs to be developed for some specific industry, some variables may be deleted and/or added. Hypothesis testing may be further used to test the validity of this hypothetical model. The ragpickers/junk dealers/members involved in recycling/reuse, i.e., 'Kabaadi-Wala' SC, have been purposed as an important area for research in context with greening.

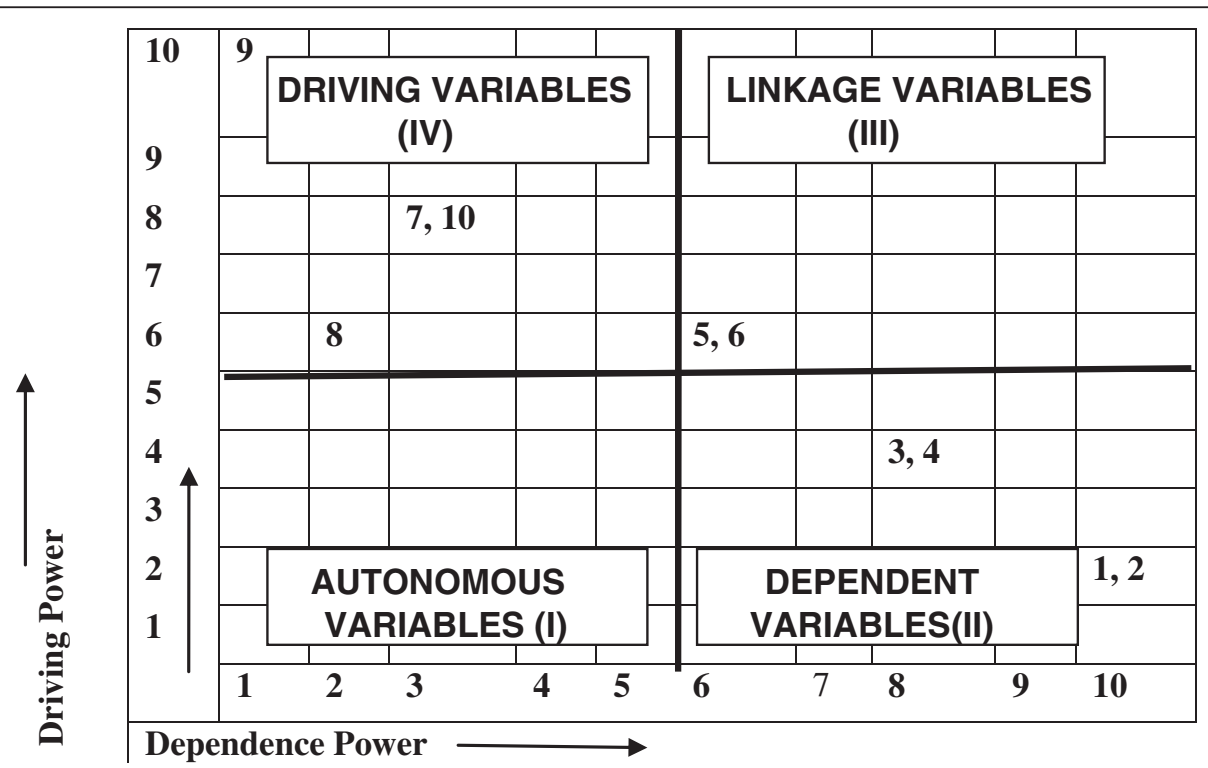

Figure 3 Clusters of variables for effective customer involvement in green concept implementation in supply chain management. 


\section{Competing interests}

The authors declare that they have no competing interests.

\section{Authors' contributions}

All authors read and approved the final manuscript.

\section{Authors' information}

Dr. Sanjay Kumar is working as a Professor in Mechanical Engineering Department at the International Institute of Technology and Management, Murthal-131039, Haryana, India. He completed his Ph.D. degree in Mechanical Engineering from Jamia Millia Islamia University, New Delhi, India. He accomplished his Master's Degree in Mechanical Engineering with specialization in Production Engineering from the Delhi Technological University, Delhi, India and Bachelor's Degree in Mechanical Engineering from the National Institute of Technology, Kurushetra, Haryana, India. He has been associated with industry and teaching in the various fields of Mechanical Engineering and operation management over 15 years. He has contributed over 20 research papers in international referred and national journals and conferences at international and national level. His specific areas of interest are industrial engineering, supply chain management, green supply chain management, etc.

Sunil Luthra is working as a lecturer in Government Polytechnic, Jhajjar. He is a research scholar (part-time) in the Mechanical Engineering Department at the National Institute of Technology, Kurukshetra, Haryana, India. He has been associated with teaching for the last 12 years. His specific areas of interest are operation management, optimization techniques, green supply chain management, etc.

Dr Abid Haleem is working as a professor and head of Mechanical Engineering at the Faculty of Engineering and Technology, Jamia Millia Islamia, New Delhi, India. He has more than 110 research papers to his credit, published in international and national journals. His research interests are egovernance, technology management, supply chain management and systems modeling, flexibility, etc. He is an editor of the Asia Pacific of Global Journal of Flexible Systems Management. He is also a member of an editorial board of contemporary management research.

\section{Acknowledgments}

The authors are very much thankful to Dr. Dixit Garg, Professor at the Department of Mechanical Engineering, Kurukshetra, India for his valuable support and guidance. The authors are also very much thankful to the unanimous reviewers, to Sherlyn C Machica, and to the language editors of the paper for their constructive and helpful comments that improved the quality of the paper.

\section{Author details}

${ }^{1}$ International Institute of Technology and Management, Murthal, Haryana 131039, India. ${ }^{2}$ National Institute of Technology, Kurukshetra, Haryana 136119, India. ${ }^{3}$ Faculty of Engineering and Technology, Jamia Mallia Islamia, New Delhi 110025, India.

\section{Received: 16 November 2012 Accepted: 9 March 2013} Published: 17 April 2013

\section{References}

Alhola KP (2008) Promoting environmentally sound furniture by green public procurement. Ecological Econ 68(1-2):472-485

Azevedo SG, Carvalho H, Machado VC (2011) The influence of green practices on supply chain performance: a case study approach. Transportation Research Part E 47(6):850-871

Bhetja AK, Babbar R, Singh S, Sachdeva A (2011) Study of green supply chain management in the Indian manufacturing industries: a literature review cum an analytical approach for the measurement of performance. IJCEM Int J of Computational Engineering \& Manage 13:84-99

Carmines E, Zeller R (1979) Reliability and validity assessment, series: quantitative applications in social science. Sage, Newbury Park, CA

Carter C, Ellram L (1998) Reverse logistics: a review of the literature and framework for future investigation. J of Business Logistics 19(1):85-102

Chan F (2003) Performance measurement in a supply chain. The Int J of Advanced Manufacturing Technology 21(7):534-548

Chien MK, Shih LH (2007a) An empirical study of the implementation of green supply chain management practices in the electrical and electronics industries and their relation to organizational performances. Int J of Science and Technology 4(3):383-394
Chien MK, Shih LH (2007b) Relationship between management practice and organization performance under European Union directives such as ROHS: a case study on the electrical and electronics industry in Taiwan. African J of Environmental Science and Technology 1(1):37-48

Christopher M (2000) The agile supply chain: competing in volatile markets. Industrial Marketing Manage 29(1):37-44

Cognizant (2009) Creating a green supply chain information technology as an enabler for a green supply chain. http://www.cognizant.com/ InsightsWhitepapers/Creating_a_Green\%20Supply_Chain_WP.pdf. Accessed 9 July 2012

Diabat A, Govidan K (2011) An analysis of the drivers affecting the implementation of green supply chain management. Resources, Conservation and Recycling 55(6):659-667

Eltayeb TK, Zailani S, Ramayah T (2011) Green supply chain initiatives among certified companies in Malaysia and environmental sustainability: investigating the outcomes. Resource, Conservation and Recycling 55(5):495-506

Fielding S (2001) ISO 14001: a plan for environmental excellence. Industrial Maintenance \& Plant Oper 62(8):11-15

Gomez LSS (2011) Identifying success factors in the wood pallet supply chain. Virginia Polytechnic Institute and State University, Virginia, Master of Science Thesis

Green K, Morton B, New S (1996) Purchasing and environmental management: interactions policies and opportunities. Business Strategy and the Environment 5(3):188-197

Green KW Jr, Zelbst PJ, Meacham J, Bhadauria VS (2012) Green supply chain management practices: impact on performance. Supply Chain Manage: An Int J 17(3):290-305

H'Mida S (2009) Factors contributing in the formation of consumers' environmental consciousness and shaping green purchasing decisions. Proceedings of the Int conference on computers \& industrial engineering 2009:957-962

Hair JF, Bush RP, Ortinau DJ (2003) Marketing Research, 2nd edn. McGraw-Hill, New Delhi

Hair JF, Black WC, Babin JB, Anderson RE, Tatham RL (2009) Multivariate data analysis(6th edition). Pearson Education, India

Hall J (2000) Environmental supply chain dynamics. J of Cleaner Prod 8(6):206-225

Hanna MD, Newman WR, Johnson P (2000) Linking operational and environmental improvement through employee involvement. Int J of Oper \& Prod Manage 20(2):148-165

Harary F, Norman R, Cartwright Z (1965) Structural models: an introduction to the theory of directed graphs. Wiley, New York

Huang X, Tan BL, Li D (2012) Pressures on green supply chain management: a study on manufacturing small and medium-sized enterprises in China. Int Business and Manage 4(1):76-82

IFS (2013) ERP for green supply chain management in manufacturing. http:// www.ifsworld.com/en/search/?searchParam=ERP\%20for\%20green\%20supply \%20chain\%20management\%20in\%20manufacturing. Accessed 9 January 2013

Ilgin MA, Gupta SM (2010) Environmentally conscious manufacturing and product recovery: a review of the state of the art. J of Environmental Manage 91(3):563-591

Israel GD (1996) Determining sample size. IFAS Extension, PEOD-6, University of Florida, edis.ifas.ufl.edu/pd006. Accessed 16 January 2013

Jharkharia S, Shankar R (2005) IT enablement of supply chains: understanding the barriers. J of Enterprise Information Manage 18(1):11-27

Lakshmi P, Visalakshmi S (2012) Managing green supply chain: initiatives and outcomes. Int J of Managing Value and Supply Chains 3(4):55-63

Lamming R, Hamapson J (1996) The environmental as a supply chain management issue. British J of Manage 7:45-62

Lazuraz L, Ketikidis PH, Bofinger AB (2011) Promoting green supply chain management: the role of the human factor.In: 15th Panhellenic Logistics Conference and 1st Southeast European Congress on Supply Chain Management. Greek Association of Supply Chain Management (EEL of Northern Greece),Thessaloniki, Greece, 11-12 November 2011. SSRN, New York, pp:1-13

Luthra S, Kumar V, Kumar S, Haleem A (2011) Barriers to implement green supply chain management in automobile industry using interpretive structural modeling technique-An Indian perspective. J of Industrial Engineering and Manage 4(2):231-257

Malhotra MK, Grover V (1998) An assessment of survey research in POM: from constructs to theory. J of Oper Manage 16(4):407-425

Mandal A, Deshmukh SG (1994) Vendor selection using interpretive structural modeling. Int J of Oper \& Prod Manage 14(6):52-59 
Mudgal RK, Shankar R, Talib P, Raj T (2009) Greening the supply chain practices: an Indian perspective of enablers' relationship. Int I of Advanced Oper Manage 1(2-3):151-176

Mudgal RK, Shankar R, Talib P, Raj T (2010) Modeling the barriers of green supply chain practices: an Indian perspective. Int J of Logistics Systems and Manage 7(1):81-107

Nunnally JC (1987) Psychometric theory. McGraw Hill, New York

Paquette J (2005) The supply chain response to Environmental Pressures Discussion., Massachusetts Institute of Technology, http://hdl.handle.net/ 1721.1/34530. Accessed 12 January 2013

Rao P, Holt D (2005) Do green supply chains lead to competitiveness and economic performance? Int J of Oper \& Prod Manage 25(9):898-916

Ravi V, Shankar R (2005) Analysis of interactions among the barriers of reverse logistics. Int J of Technological Forecasting and Social change 72:1011-1029

Rea LM, Parker RA (2005) Designing and conducting survey research: a comprehensive guide, 3rd edn. Jossey-Bass, San Francisco

Reijonen S (2011) Environmentally friendly consumer: from determinism to emergence. Int J of Consumer Studies 35(4):403-409

Sage A (1977) Interpretive structural modeling: methodology for large scale systems. McGraw-Hill, New York, pp 91-164

Sarkis J, Hasan MA, Shankar R (2007) Evaluating environmentally conscious manufacturing barriers with interpretive structural modeling. http://dx.doi. org/10.2139/ssrn.956954

Sekaran U (2003) Research methods for business: askill building approach, 5th edn. Wiley, Singapore

Shi VG, Lenny Koh SC, Baldwin J, Cucchiella F (2012) Natural resource based green supply chain management. Supply Chain Manage: An Int J 17(1):54-67

Simpson D, Power D, Samson D (2007) Greening the automotive supply chain: a relationship perspective. Int J of Oper \& Prod Manage 27(1):28-48

Singh MD, Kant R (2008) Knowledge management barriers: an interpretive structural modeling approach. Int I of Manage Science and Engineering Manage 3(2):141-150

Srivastva S (2007) Green supply chain management: a state of the art literature review. Int J of Manage Review 9(1):53-80

Sushil (2005) Interpretive matrix: a tool to aid interpretation of management and social research. Global J of Flexible Systems Manage 6(2):27-30

Tan KC, Kannan VR, Handfield RB (1998) Supply chain management: supplier performance and firm performance. Int $J$ of Purchasing and Material Manage $34(3): 2-9$

Theyel G (2006) Customer and Supplier Relations for Environmental Performance. In: Sarkis J (ed) Greening the Supply Chain. Springer, Berlin, pp 139-150

Thomas AVand Bijulal D (2011) Closed-loop supply chains: the green practices in supply chains.In: National technological congress, College of Engineering Trivandrum, Kerala, 28-29 January 2011. NATCON 2011, Ottawa, pp. 196-199Torielli RM, Abrahams RA, Smillie RW, Voigt RC (2011) Using lean methodologies for economically and environmentally sustainable foundries. China Foundry 8(1):74-88

Vachon S, Klassen RD (2006a) Extending green practices across the supply chain: the impact of upstream and downstream integration. Int J of Oper \& Prod Manage 26(7):795-821

Vachon S, Klassen RD (2006b) Green project partnership in the supply chain: the case of the package printing industry. J of Cleaner Prod 14(6-7):661-71

Vachon S, Klassen RD (2008) Environmental management and manufacturing performance: the role of collaboration in the supply chain. Int J of Prod Econ 111(2):295-308

Walker H, Sisto L, McBain D (2008) Drivers and barriers to environmental supply chain management practices: lessons from the public and private sectors. of Purchasing \& Supply Manage 14(1):69-85

Wang HF, Gupta SM (2011) Green supply chain management: product life cycle approach, 1stedition, McGraw Hill, New York. Wang ML, Kuo TC, Wen LJ (2009) Identifying target green 3C customers in Taiwan using multiattribute utility theory. Expert Systems with Applications 36(10)):12562-12569

Warfield JW (1974) Developing interconnected matrices in structural modeling. IEEE Transcript on Systems, Men and Cybernetics 4(1):51-81

Wu GC, Cheng YH, Hang SY (2010) The study of knowledge transfer and green management performance in green supply chain management. African J of Business Manage 4(1):44-48

Wu KL, Tseng ML, Vy T (2011) Evaluation the drivers of green supply chain management practices in uncertainty. Procedia-Social and Behavioral Sciences 25:384-397

Yang J, Wong CWY, Lai KH, Ntoko AN (2009) The antecedents of dyadic quality of performance and its effect on buyer-supplier relationship improvement. Int J of Prod Econ 102(1):243-51
Yu LC (2007) J of Manage Study August, Adoption of green supply in Taiwan logistic industry, pp 90-98

Yu LC, Hui HY (2008) An empirical study on logistics services provider, intention to adopt green innovations. J of Technology, Manage and Innovation 3(1):17-26

Zhu Q, Sarkis J (2004) Relationships between operational practices and performance among early adopters of green supply chain management practices in Chinese manufacturing enterprises. J of Oper Manage 22(3):265-289

Zhu Q, Sarkis J (2006) An inter-sectoral comparison of green supply chain management in China: drivers and practices. J of Cleaner Prod 14(5):71-74

Zhu Q, Sarkis J, Lai KH (2007a) Green supply management: pressures, practices and performance within the Chinese automobile industry. J of Cleaner Prod 15(11-12):1041-1052

Zhu Q, Sarkis J, Lai KH (2007b) Initiatives and outcomes of green supply chain management implementation by Chinese manufacturers. J of Environmental Manage 85(1):179-189

Zhu Q, Sarkis J, Lai KH (2008a) Confirmation of a measurement model for green supply chain management practices implementation. Int I of Prod Econ 111(2):261-273

Zhu Q, Sarkis J, Lai KH (2008b) Green supply chain management implications for "closing the loop". Transportation Research Part E 44(1):1-18

Zhu Q, Geng Y, Lai KH (2010) Circular economy practices among Chinese manufacturers varying in environmental-oriented supply chain cooperation and the performance implications. J of Environmental Manage 91(6):1324-1331

\section{doi:10.1186/2251-712X-9-6}

Cite this article as: Kumar et al:: Customer involvement in greening the supply chain: an interpretive structural modeling methodology. Journal of Industrial Engineering International 2013 9:6.

\section{Submit your manuscript to a SpringerOpen ${ }^{\circ}$ journal and benefit from:}

- Convenient online submission

- Rigorous peer review

- Immediate publication on acceptance

- Open access: articles freely available online

- High visibility within the field

- Retaining the copyright to your article

Submit your next manuscript at $>$ springeropen.com 